\title{
Ovariectomy is associated with metabolic impairments and enhanced mammary tumor growth in MKR mice
}

\author{
Sarit Ben-Shmuel ${ }^{1, *}$, Eyal J Scheinman ${ }^{1, *}$, Rola Rashed', Zila Shen Orr', \\ Emily J Gallagher ${ }^{2}$, Derek LeRoith ${ }^{1,2}$ and Ran Rostoker ${ }^{1}$ \\ ${ }^{1}$ Clinical Research Institute at Rambam (CRIR), Diabetes and Metabolism Clinical Research Center of Excellence, \\ Rambam Medical Center, PO Box 9602, Haifa 31096, Israel \\ ${ }^{2}$ Division of Endocrinology, Diabetes and Bone Diseases, Icahn School of Medicine at Mount Sinai, One Gustave L. \\ Levy Place, PO Box 1055, Atran 4-36, New York, New York 10029, USA \\ *(S Ben-Shmuel and E J Scheinman contributed equally to this work)
}

\author{
Correspondence \\ should be addressed \\ to D LeRoith \\ Email \\ d_leroith@ \\ rambam.health.gov.il
}

\begin{abstract}
Obesity and type 2 diabetes (T2D) are associated with an increased risk of breast cancer incidence and mortality. Common features of obesity and T2D are insulin resistance and hyperinsulinemia. A mammary tumor promoting effect of insulin resistance and hyperinsulinemia was demonstrated in the transgenic female MKR mouse model of pre-diabetes inoculated with mammary cancer cells. Interestingly, in MKR mice, as well as in other diabetic mouse models, males exhibit severe hyperglycemia, while females display insulin resistance and hyperinsulinemia with only a mild increase in blood glucose levels. This gender-specific protection from hyperglycemia may be attributed to estradiol, a key player in the regulation of the metabolic state, including obesity, glucose homeostasis, insulin resistance, and lipid profile. The aim of this study was to investigate the effects of ovariectomy (including the removal of endogenous estradiol) on the metabolic state of MKR female mice and subsequently on the growth of Mvt-1 mammary cancer cells, inoculated into the mammary fat pad of ovariectomized mice, compared with sham-operated mice. The results showed an increase in body weight, accompanied by increased fat mass, elevated blood glucose levels, and hypercholesterolemia, in ovariectomized MKR mice. In addition, mammary tumor growth was significantly higher in these mice. The results suggest that ovarian hormone deficiency may promote impaired metabolic homeostasis in the hyperinsulinemic MKR female mice, which in turn is associated with an increased growth of mammary tumors.
\end{abstract}

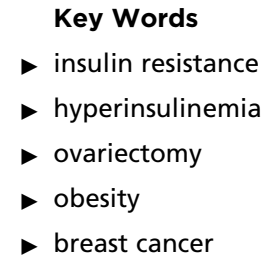

Journal of Endocrinology (2015) 227, 143-151

\section{Introduction}

Numerous studies and meta-analyses confirm the association between type 2 diabetes (T2D) mellitus and an increased risk of breast cancer incidence and mortality in postmenopausal women (Michels et al. 2003, Coughlin et al. 2004, Larsson et al. 2007). Hyperglycemia, insulin resistance, and subsequently hyperinsulinemia, key features of $\mathrm{T} 2 \mathrm{D}$, have been suggested as potential molecular mechanisms underlying this association (Novosyadlyy \& LeRoith 2010, Xu et al. 2014). Novosyadlyy et al. (2010) demonstrated the mammary tumor promoting effect of

Published by Bioscientifica Ltd. 
hyperinsulinemia in the transgenic female MKR mouse model of T2D inoculated with mammary cancer cells. Interestingly, female MKR mice exhibit marked hyperinsulinemia and insulin resistance, but only a mild increase in blood glucose levels, compared with male MKR mice, which manifest severe diabetes (Fernandez et al. 2001). This gender-specific phenomenon was observed in Zucker diabetic fatty rats (Clark et al. 1983), as well as in obese Agouti yellow mice (Klebig et al. 1995). In streptozotocin (STZ)-induced diabetes, male mice were susceptible to STZ, while female mice were resistant, unless they were ovariectomized (Paik et al. 1982, Puah \& Bailey 1985). Therefore, the gender-specific protection from hyperglycemia may be attributed to ovarian hormones.

It is now evident that estradiol plays an important role in several physiological and pathophysiological states, including obesity, glucose homeostasis, and insulin resistance (Louet et al. 2004, Barros \& Gustafsson 2011). Supporting the beneficial effects of estradiol on metabolic homeostasis are studies showing greater insulin sensitivity in premenopausal women compared with age-matched men (Nuutila et al. 1995, Donahue et al. 1997), as well as a reduced incidence of T2D in postmenopausal women subjected to hormone replacement therapy (HRT) (Margolis et al. 2004). In addition, it was shown that estradiol deficiency in postmenopausal women leads to increased body weight, which was associated with an increase in abdominal fat (Lovejoy et al. 2008). The metabolic effects of estradiol are suggested to be mediated by estrogen receptor (ER) $\alpha$, as both male and female ER $\alpha$ knockout mice exhibit glucose intolerance and insulin resistance, along with increased weight gain and fat mass (Heine et al. 2000).

In this study, we investigated whether the removal of ovarian hormones (including estradiol) by ovariectomy could exacerbate the mild diabetic features observed in female MKR mice compared with male MKR mice. In addition, we investigated the effects of ovariectomy and the consequent alterations in the metabolic phenotype on the growth of Mvt-1 mammary cancer cells inoculated into the mammary fat pad of these ovariectomized female MKR mice (MKR-OVX). Our results indeed show increased weight gain in MKR-OVX mice compared with shamoperated MKRs (MKR-Sham), which was accompanied by increased inguinal fat as well as elevated fasting and non-fasting blood glucose levels and hypercholesterolemia. In addition, mammary tumor growth was significantly higher in MKR-OVX mice compared with MKR-Sham mice, associated with higher activation of the phosphoinositide 3 kinase (PI3K)/Akt signaling pathway in tumor cells of MKR-OVX group. These results suggest that ovarian hormones may have a protective effect on the metabolic state in MKR female mice. Impairments in metabolic homeostasis caused by ovariectomy are associated with increased mammary tumor growth.

\section{Material and methods}

\section{Animals}

MKR mice were used in this study. The generation of MKR transgenic mice (on the $\mathrm{FVB} / \mathrm{N}$ background), carrying a dominant-negative insulin-like growth factor 1 (IGF1) receptor (IGF1r) specifically targeted to the skeletal muscle, has been described previously (Fernandez et al. 2001). Mice were fed standard chow and water and allowed to feed ad libitum and were kept on a $12 \mathrm{~h}$ light:12 h darkness cycle. Mice studies were performed according to the protocol approved by the Technion Animal Inspection Committee. Technion holds a National Institutes of Health (NIH) animal approval (license number A5026-01). MKR mice were subjected to sham surgery (MKR-Sham) or ovariectomy (MKR-OVX) at 6 weeks of age. Briefly, mice were anesthetized with isoflurane, and buprenorphine $(50 \mu \mathrm{l}$ of $0.03 \mathrm{mg} / \mathrm{ml}$ solution) was administered s.c. as an analgesic. A short dorsal midline incision was made, and ovaries and oviducts were exteriorized through muscle wall incisions bilateral to the spine. The oviduct was ligated and the ovary was removed by a single cut. Remaining tissue was replaced into the peritoneal cavity and skin was sutured.

Food was weighed every 3-4 days. Food intake is presented as daily intake $(\mathrm{g})$ per $100 \mathrm{~g}$ mice.

\section{Cell culture}

Mvt-1 mouse mammary cancer cells were derived from $M M T V-c-M y c / V e g f$ transgenic mice tumor explants, as previously described (Pei et al. 2004). Cells were cultured in DMEM (Biological Industries, Beit Haemek, Israel) supplemented with $10 \% \mathrm{v} / \mathrm{v}$ fetal bovine serum (Biological Industries) and $1 \% \mathrm{v} / \mathrm{v}$ penicillin:streptomycin (Biological Industries). Cells were maintained at $37^{\circ} \mathrm{C}$ in a humidified atmosphere consisting of $5 \% \mathrm{CO}_{2}$ and $95 \%$ air.

\section{Syngeneic orthotopic tumor models}

Mvt-1 cells were detached with trypsin solution (Biological Industries) into single cells and suspended in PBS at a

Published by Bioscientifica Ltd. 
concentration of $0.5 \times 10^{6}$ cells $/ \mathrm{ml} ; 100 \mu \mathrm{l}$ (50 000 cells) were then injected into the left inguinal mammary fat pads (no. 4) of MKR-Sham or MKR-OVX mice, 35 days after ovariectomy (11 weeks old).

Tumor volume was monitored once a week using calipers and calculated in $\mathrm{mm}^{3}$ by the formula: width ${ }^{2} \times$ length $\times 0.5$. At sacrifice, tumors were removed and weighed.

\section{Blood glucose measurement}

Blood glucose levels were measured weekly in a nonfasting state. Blood samples were taken from the tail vein and glucose levels were determined using an automated glucometer (Accu-Check Preforma System, Roche Diagnostics, Mannheim, Germany).

\section{Body composition}

Body composition was measured every 2 weeks and was determined in non-anesthetized mice using the NMR analyzer (Minispec LF50/mq7.5 Analyzer, Bruker Optic $\mathrm{GmbH}$, Germany). Results are presented as the ratio between fat mass and lean mass.

At sacrifice, inguinal fat was collected and weighed. Results are presented as inguinal fat mass percent of total body weight.

\section{Glucose-tolerance test and insulin-tolerance test}

A glucose-tolerance test (GTT) and insulin-tolerance test (ITT) were performed during daylight time, after $4 \mathrm{~h}$ fasting. Glucose $(2 \mathrm{~g} / \mathrm{kg}$ body weight $)$ or insulin (12 IU/kg, NovoRapid Vial, Novo Nordisk, Bagsvaerd, Denmark) were administered i.p. Blood glucose levels were measured at the indicated time points.

\section{Serum analysis}

At sacrifice, blood samples were taken from the heart of anesthetized mice. Blood was allowed to clot and was then centrifuged for $10 \mathrm{~min}$ at $6000 \mathrm{~g} 4^{\circ} \mathrm{C}$. Supernatant (serum) was collected into a fresh tube and maintained in $-80^{\circ} \mathrm{C}$ for analysis. Serum insulin, leptin, and adiponectin levels were measured with Rat/Mouse Insulin 96-Well Plate Assay Kit, Mouse Leptin 96-Well Plate Assay Kit, and Mouse Adiponectin 96-Well Plate Assay Kit, respectively (Millipore, Billerica, MA, USA) according to manufacturer's instructions. Data acquisition was performed using the PowerWave XS2 (BioTek, Winooski, VT, USA) and
Gen5 Software. Cholesterol and triglycerides were measured by Siemens Dimension analyzer (Siemens Healthcare, Erlangen, Germany).

\section{Protein extraction and western blot analysis}

Tumors were homogenized in lysis buffer $(10 \mathrm{mmol} / \mathrm{l}$ Tris-HCl pH 7.5, $150 \mathrm{mmol} / \mathrm{l}$ sodium chloride, $10 \mathrm{mmol} / \mathrm{l}$ sodium pyrophosphate, $1 \mathrm{mmol} / 1 \quad \beta$-glycerolphosphate, $1 \mathrm{mmol} / \mathrm{l}$ sodium orthovanadate, $50 \mathrm{mmol} / \mathrm{l}$ sodium fluoride, $1.25 \% \mathrm{v} / \mathrm{v}$ CHAPS (3-((3-cholamidopropyl) dimethylammonio)-1-propanesulfonate), and Complete Protease Inhibitor Cocktail (Roche Diagnostics). Lysates were rotated at $4{ }^{\circ} \mathrm{C}$ for $1 \mathrm{~h}$ and centrifuged at $16000 \mathrm{~g}$ for $10 \mathrm{~min}$. Supernatants were collected and protein concentrations were determined with Protein Assay Kit (Bio-Rad). Protein $(12 \mu \mathrm{g})$ was electrophoresed through a $10 \%$ polyacrilamide gel and transferred to a nitrocellulose membrane. The membranes were immunoblotted with the desired antibody, followed by an appropriate secondary antibody conjugated with horseradish peroxidase (Jackson ImmunoResearch Laboratories, West Grove, PA, USA). Immunoreactivity was detected by ECL (WesternBright Quantum Western blotting detection kit, Advansta, Melano Park, CA, USA), using luminescent image analyzer LAS-4000 (Fujifilm, Tokyo, Japan). Densitometry analysis was performed using ImageQuant Software (GE Healthcare Bio-Sciences, Pittsburgh, PA, USA).

The following antibodies were used: Phospho-Akt (Thr308), total-Akt, and $\beta$-actin (Cell Signaling Technology, Danvers, MA, USA).

\section{Statistical analysis}

Results are presented as mean \pm s.E.M. Statistical analyses were performed using GraphPad Prism (Version 5; GraphPad Software, Inc., La Jolla, CA, USA). The Student's $t$-test and two-way ANOVA, followed by Bonferroni multiple comparison post-test, were used to determine the statistical significance of differences between groups. $P<0.05$ was considered statistically significant.

\section{Results}

Sham surgery and ovariectomy of MKR mice (MKR-Sham and MKR-OVX respectively) were performed at 6 weeks of age. At the beginning of the experiment, body weights of all mice were similar (Fig. 1A). However, 2 weeks after surgery an increased weight gain was observed in MKROVX group compared with MKR-Sham mice. Maximum

Published by Bioscientifica Ltd. 

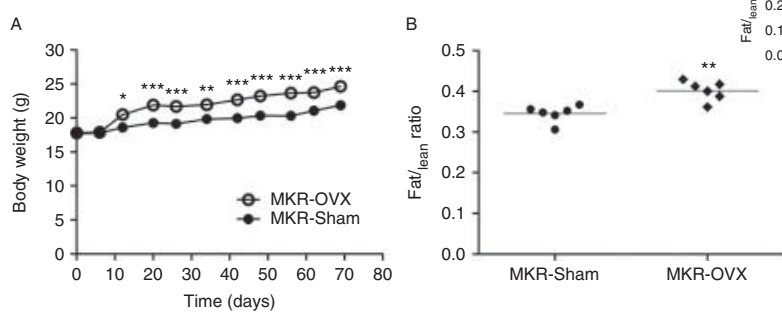
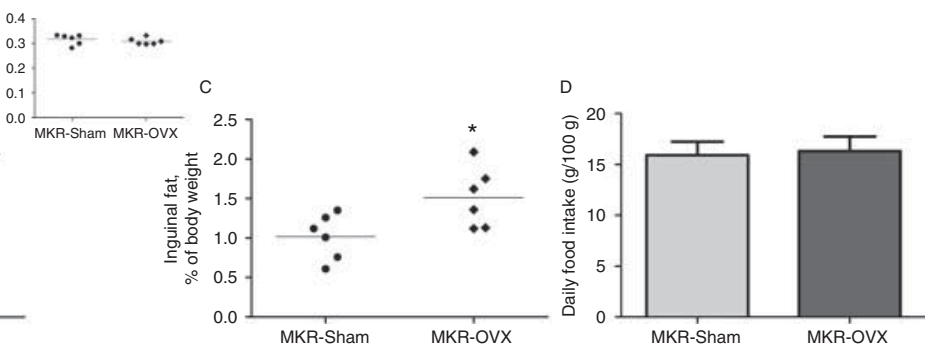

\section{Figure 1}

Ovariectomy leads to increased body weight and fat mass in MKR mice. (A) Body weight was followed on a weekly basis from before surgery (day 0 ) until sacrifice. Results are representatives of two independent experiments and presented as mean \pm S.E.M., $n=10$. (B) Body composition was analyzed every 2 weeks. Results are representative of the three last analyses before sacrifice and presented as the ratio between fat mass and lean mass for each mouse + mean, $n=6$. Panel: body composition results before surgery.
(C) Inguinal fat was collected and weighed at sacrifice. Results are presented as inguinal fat mass percent of total body weight for each mouse + mean, $n=6$. (D) Food was weighed every 3-4 days. Food intake is presented as mean \pm s.E.M. of daily intake (g) per $100 \mathrm{~g}$ mice, $n=6$. Two-way ANOVA followed by Bonferroni multiple comparison post-test (A) or Student's $t$-test ( $B, C$ and $D$ ) were used to determine statistical significance; ${ }^{*} P<0.05, * * P<0.01, * * * P<0.001$ vs MKR-Sham. difference in body weight of $3 \mathrm{~g}$ was reached 3 weeks after surgery and remained constant until the end of the experiment. Body composition results, presented as the ratio between fat mass and lean mass, were also similar between the two groups at the beginning of the experiment (Fig. 1B panel). However, at the end of the experiment, the fat-to-lean ratio of ovariectomized mice was significantly higher by $16 \%$ than the ratio calculated for sham-operated mice (Fig. 1B). To support this result, inguinal fat was weighed at sacrifice and presented as percent of total body weight (Fig. 1C). Indeed, the percentage of inguinal fat mass in MKR-OVX mice was higher by 1.5 -fold than in MKR-Sham mice. Daily food intake was similar for both groups (Fig. 1D).

Blood glucose levels on the day of the surgery and 2 weeks after surgery were similar for both MKR groups (Fig. 2A). In parallel to the increase in body weight, blood
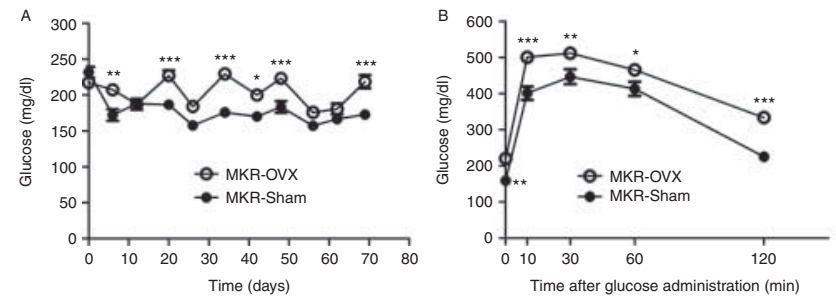

Figure 2

Ovariectomy leads to increased blood glucose levels under fasting and nonfasting conditions. (A) Blood glucose levels under non-fasting conditions were followed on a weekly basis from before surgery (day 0 ) until sacrifice. (B) GTT: glucose $(2 \mathrm{~g} / \mathrm{kg})$ was administered i.p. to fasting mice, and blood glucose was measured at the indicated times. (C) Area under the curve for each group was calculated above the respective baseline using GraphPad Prism Software. (D) ITT: insulin (12 IU/kg) was administered i.p. to fasting glucose levels 3 weeks after surgery were significantly higher for MKR-OVX mice compared with MKR-Sham mice. Overall, glucose levels remained elevated by about $20 \%$ in the MKR-OVX group until the end of the experiment. Glucose tolerance and insulin sensitivity were also studied in MKR-OVX and MKR-Sham mice. Fasting glucose (blood glucose at time 0 , before glucose load) was significantly higher in MKR-OVX mice compared with MKR-Sham groups (Fig. 2B). Blood glucose levels remained elevated for the MKR-OVX group throughout the assay. However, calculation of the area under the curve from the baseline of each group resulted in similar values (Fig. 2C). These data suggest that the elevated glucose levels observed after glucose load emanate from higher baseline glucose levels and that glucose tolerance in ovariectomized MKR mice is similar to sham-operated mice. Insulin resistance (Fig. 2D), as well
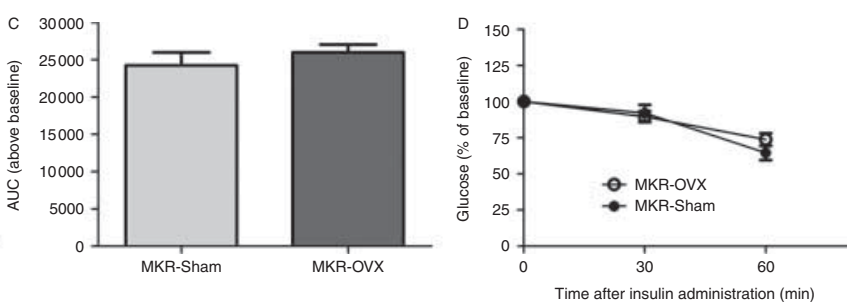

mice, and blood glucose was measured at the indicated times. Results are representatives of three independent experiments and presented as mean \pm s.E.M., $n=10$. Two-way ANOVA followed by Bonferroni multiple comparison post-test ( $A, B$ and $D$ ) or Student's $t$-test (C) were used to determine the statistical significance; ${ }^{*} P<0.05, * * P<0.01, * * * P<0.001$ vs MKR-Sham

Published by Bioscientifica Ltd. 
Table 1 Serum analysis of metabolic parameters. Data represent the mean \pm s.E.M., $n \geq 13$. Student's $t$-test was used to determine the statistical significance

\section{Parameter}

Insulin (ng/ml)

Triglycerides $(\mathrm{mg} / \mathrm{dl})$

Adiponectin $(\mu \mathrm{g} / \mathrm{ml})$

\begin{tabular}{ccc}
\hline MKR-Sham & & MKR-OVX \\
\hline $5.35 \pm 0.68$ & & $6.40 \pm 0.57$ \\
$314 \pm 50$ & & $313 \pm 55$ \\
$3.74 \pm 0.27$ & & $4.10 \pm 0.26$ \\
\hline
\end{tabular}

as serum levels of insulin, triglycerides, and adiponectin (Table 1), was also similar between the two MKR groups. Serum cholesterol levels were significantly higher by $30 \%$ in MKR-OVX mice compared with the MKR-Sham group (Fig. 3A). Interestingly, MKR-OVX mice showed a twofold increase in serum leptin levels compared to MKR-Sham mice (Fig. 3B).

Mvt-1 mammary tumor cells were inoculated into the inguinal mammary fat pad of the MKR-OVX and MKRSham groups (50 000 cells per mouse). At the time of inoculation, the differences in body weight and glucose homeostasis between MKR-OVX and MKR-Sham mice had stabilized, indicating an existing effect of ovariectomy on the metabolic state of MKR mice. Tumor volume assessments commenced as tumors were detected and continued on a weekly basis until sacrifice. A gradual increase in the rate of tumor growth was observed in ovariectomized MKR mice (Fig. 4A). At the time of sacrifice (38 days after cells inoculation), the tumors of MKR-OVX mice were significantly larger (by approximately 40\%) than MKR-Sham tumors. Also, tumor weights were higher in MKR-OVX mice compared with MKR-Sham mice (Fig. 4B). Western blot analysis of protein extracted from tumors at the end of the experiment showed an increase in phosphoAkt (Thr308) levels by threefold in MKR-OVX mice compared with MKR-Sham mice (Fig. 4C and D), indicating that the tumorigenic outcome of ovarian hormone deficiency in MKR mice is mediated through activation of the PI3K/Akt pathway signaling pathway.

\section{Discussion}

The results from this study suggest that ovarian hormones may have a protective effect on the metabolic state and consequently on mammary tumor development in MKR female mice. The effects of ovariectomy in these transgenic mice were evident by the increased body weight and fat mass, elevated blood glucose levels (in both fasting and non-fasting conditions), and increased mammary tumor growth in ovariectomized mice compared with shamoperated mice.

It is known that estradiol plays a role in the regulation of obesity and fat accumulation in both human and animal models. The prevalence of obesity markedly increases with the decline in estradiol levels following menopause (Carr 2003). Ovariectomized mice fed a high fat diet showed increased body weight and fat mass compared with sham-operated mice (Camporez et al. 2013). In the present study, we show increased body weight, which was accompanied by increased body fat mass, in ovariectomized hyperinsulinemic MKR female mice (fed regular chow) compared with sham-operated mice. The effects of estradiol on body weight are suggested to be mediated by ER $\alpha$-expressing cells in the hypothalamus, which are involved in the regulation of energy intake and expenditure (Xu et al. 2011). In the present study, we hypothesize that the differences in body weight and fat mass between MKR-OVX and MKR-Sham mice were due to decreased energy expenditure of ovariectomized mice, because daily food intake was similar for both groups. Our hypothesis is supported by previous reports showing similar effects (Rogers et al. 2009, Camporez et al. 2013).

The MKR transgenic mouse model has been previously shown to have insulin resistance and elevated insulin levels in serum compared with WT mice (Fernandez et al. 2001). We verified these characteristics in both MKR-OVX and MKR-Sham mice compared with age-matched WT mice (data not shown). It has been shown that estradiol deficiency leads to hyperglycemia and insulin resistance in postmenopausal women and mouse models (Heine et al. 2000, Carr 2003, Yakar et al. 2006). In the present study, fasting and non-fasting blood glucose levels were elevated in ovariectomized MKR mice, suggesting that estradiol may be involved in glucose homeostasis in
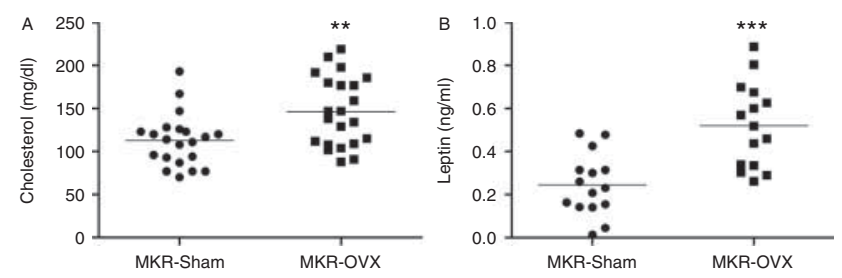

\section{Figure 3}

Ovariectomy leads to increased cholesterol and leptin levels in serum of MKR mice. At the end of the experiment, blood samples were taken from the heart of anesthetized mice, and serum was collected and used for (A) cholesterol and (B) leptin measurements. Results are the sum of data from three independent experiments and presented as raw data + mean, (A) $n=21$, (B) $n=15$. Student's $t$-test was used to determine the statistical significance; $* * P<0.01, * * * P<0.001$ vs MKR-Sham.

Published by Bioscientifica Ltd. 

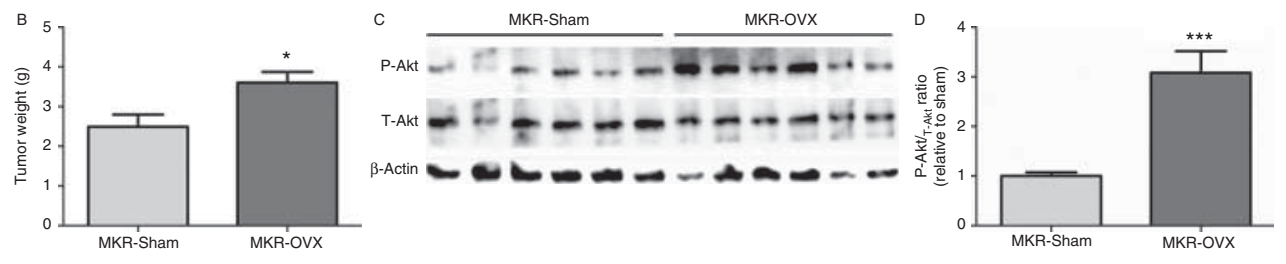

\section{Figure 4}

Ovariectomy leads to increased mammary tumor growth in MKR mice and activated Akt signaling in inoculated tumor cells. Mvt-1 mammary tumor cells (50 000 cells) were inoculated into the mammary fat pad of ovariectomized and sham-operated MKR mice. (A) After detection of tumors, tumor volume was assessed at the indicated times. (B) Tumor weight was measured at sacrifice. (C) Protein was extracted from tumors and western blot analysis was performed using antibodies directed against

hyperinsulinemic MKR mice. Glucose and ITTs, as well as serum insulin levels, were similar for both MKR groups. However, because insulin sensitivity is markedly impaired in both MKR groups, it may be reasonable to assume that ovariectomy would not have further effects on insulin resistance. There are several mechanisms by which estradiol affects glucose homeostasis including an increase in the insulin production capacity of $\beta$-cells in the pancreas (Choi et al. 2005), an increase in hepatic insulin sensitivity by suppressing liver enzymes involved in gluconeogenesis and glycogenolysis pathways (Bryzgalova et al. 2006), and an induction of the expression of glucose transporters, mainly GLUT4, in skeletal muscles, thereby increasing glucose uptake by the tissue (Barros et al. 2006). Because serum insulin levels and insulin resistance are similar for both MKR groups, we suggest that the increased baseline glucose levels observed in MKR-OVX mice are mainly due to increased glucose output from the liver.

As in the case of energy and glucose homeostasis, estradiol is known to have beneficial effects on lipid profile. Treatment of mice with ER $\alpha$ - and ER $\beta$-selective agonists resulted not only in reduced weight and fat mass but also in decreased plasma cholesterol (Lemieux et al. 2005, Yepuru et al. 2010). Also, female aromatase knockout mice show hypercholesterolemia (but not hypertriglyceridemia) (Jones et al. 2000). Moreover, postmenopausal women undergoing HRT showed a significant reduction in total serum cholesterol levels (Espeland et al. 1998). In the present study, ovariectomy indeed led to increased cholesterol levels. A direct link between estradiol protective effects and cholesterol homeostasis was proposed by De Marinis et al. (2008). The authors suggested that the presence of estradiol leads to reduced expression and activity of the enzyme 3-hydroxy 3-methylglutaryl
phospho-Akt (Thr308, P-Akt), total-Akt (T-Akt), and $\beta$-actin. (D) Densitometry analysis was performed using ImageQuant Software. Results are representative of two independent experiments and presented as mean \pm S.E.M., $n=6$. Two-way ANOVA followed by Bonferroni multiple comparison post-test $(A)$ or Student's $t$-test ( $B$ and $D$ ) were used to determine the statistical significance; ${ }^{*} P<0.05, * * * P<0.001$ vs MKR-Sham.

coenzyme A reductase, the rate-limiting enzyme in the synthesis process of cholesterol.

Ovariectomy in MKR mice led to an increased mammary tumor volume and weight. To understand the possible mechanisms underlying the changes in tumor measurements, we investigated the activation of the PI3K/Akt pathway. The PI3K/Akt pathway is activated by hormones and growth factors and has been well established to play a significant role in cell proliferation and survival, thereby leading to tumor growth (Paplomata \& O'Regan 2014). Indeed, the Akt protein was activated (phosphorylated) to a higher degree in tumor cells inoculated into ovariectomized MKR mice. The MAPK/ ERK pathway, also involved in cell proliferation processes (Makin \& Dive 2001), showed a similar degree of activation in tumor cells of both MKR groups (data not shown). In general, estradiol is thought to promote breast cancer development by inducing transformation, proliferation, and DNA damage (Preston-Martin et al. 1990, Russo et al. 2006) by both ER-dependent and independent mechanisms (Yue et al. 2013). However, anti-cancer actions of estradiol have also been reported (Anderson et al. 2004, LaCroix et al. 2011). These data give rise to an ongoing debate on whether HRT increases or decreases the risk of breast cancer (Chlebowski \& Anderson 2012). On the other hand, the association of HRT with a reduced risk of diabetes and an overall improvement in metabolic parameters, such as insulin sensitivity, blood glucose levels, obesity, and lipids profile, is less controversial (Margolis et al. 2004, Salpeter et al. 2006, Bhupathiraju \& Manson 2014). In light of these observations, we suggest that ovariectomy does not affect mammary tumor growth directly, but rather indirectly, through changes in the environment of the tumor cells. The metabolic

Published by Bioscientifica Ltd 
impairments induced by ovarian hormone deficiency i.e., increased body weight, accumulation of fat mass, hyperglycemia, and hypercholesterolemia - are good candidates for mediating the tumorigenic outcome of ovariectomy, as they all favor tumor growth (as discussed below). Specifically, Mvt-1 cells do not express ER (data not shown), indicating that mammary tumor growth in our model is independent on the presence of estradiol, further supporting our suggestion.

Studies claim that obesity is a risk factor for breast cancer (Petrelli et al. 2002, Pierobon \& Frankenfeld 2013, Robinson et al. 2014). Obesity may contribute to mammary tumor development through several mechanisms. Systemically, obesity is associated with insulin resistance and hyperinsulinemia and an increased bioavailability of several growth factors and adipokines, such as leptin, which is known to activate the PI3K/Akt signaling pathway and promote tumor growth, as reviewed by Hursting et al. (2012). In addition, obesity leads to subclinical inflammation in adipose tissue, which is characterized by macrophages surrounding necrotic adipocytes and forming crown-like structures (CLS) (Cinti et al. 2005). The local production of pro-inflammatory mediators in breast tissue, as evident by the increased numbers of CLS in mammary glands of obese mice and women (Morris et al. 2011, Subbaramaiah et al. 2011), is known to promote angiogenesis and to increase cancer progression (Sundaram et al. 2013). Hypercholesterolemia is also associated with the risk of breast cancer (Kitahara et al. 2011). ApoE knockout mice, which demonstrate high cholesterol and triglycerides levels in serum, were shown to have enhanced mammary tumor growth. Cholesterol-induced activation of the PI3K/Akt signaling pathway in tumor cells was suggested as the molecular mechanism linking hypercholesterolemia and tumor growth (Alikhani et al. 2013). Hyperglycemia can promote cancer growth by simply providing the energy necessary for cell proliferation and neoangiogenesis (Sciacca et al. 2013).

Although ovariectomy led to impairments in metabolic homeostasis in MKR female mice, the changes in metabolic parameters were moderate and did not reach the drastic levels of hyperglycemia and glucose intolerance reported previously for male MKR mice (Fernandez et al. 2001), suggesting that other factors, aside from estradiol, may play a role in metabolic control in the female MKR model. An important candidate may be progesterone, which has also been implicated in the regulation of metabolic homeostasis. However, while estradiol plays a protective role in metabolic control, progesterone promotes metabolic impairments, such as insulin resistance and hyperglycemia (Gonzalez et al. 2000; Picard et al. 2002). Thus, it is possible that the moderate metabolic impairments observed in MKR-OVX mice are the result of the interplay between estradiol and progesterone withdrawal caused by the removal of ovaries.

Insulin resistance and, subsequently, increased levels of insulin, with its cell proliferation effect, often stand at the basis of the association between T2D and breast cancer progression (Novosyadlyy et al. 2010). Interestingly, both ovariectomized and sham-operated mice in this study are insulin resistant and hyperinsulinemic. Nonetheless, the changes in metabolic parameters observed in ovariectomized MKR mice were able to drive mammary tumor growth at a higher rate than in sham-operated MKR mice. These results suggest that in the face of previously existing insulin resistance and hyperinsulinemia, other metabolic impairments (i.e., obesity, hyperglycemia and hypercholesterolemia) may promote the growth of mammary tumors.

Taken together, we suggest a protective role of ovarian hormones on the metabolic state of the female MKR transgenic mouse model for T2D. Ovariectomy leads to impaired metabolic homeostasis in MKR mice, manifested by increased body weight and fat mass, as well as hypercholesterolemia and hyperglycemia, which in turn is associated with an increased growth of mammary tumors in the face of insulin resistance and hyperinsulinemia in MKR mice. These results highlight the importance of closely monitoring and maintaining balanced body weight, as well as glucose and cholesterol levels, specifically in diabetic postmenopausal women, as impairments in these parameters may favor breast cancer outcome and/or worsening of breast cancer prognosis.

Declaration of interest

The authors declare that there is no conflict of interest that could be perceived as prejudicing the impartiality of the research reported.

\section{Funding}

This work was supported by grants from the Diabetes and Metabolism Clinical Research Center of Excellence, Clinical Research Institute at Rambam (to $D L R$ ), the Israel Science Foundation grant (to $D L R$ ), $N C$ I (grant number 2R01CA128799-06A1 to D L R), and NIH/NCl (grant number 1 K08CA190770 grant to $E J G$ ).

\section{References}

Alikhani N, Ferguson RD, Novosyadlyy R, Gallagher EJ, Scheinman EJ, Yakar S \& LeRoith D 2013 Mammary tumor growth and pulmonary metastasis are enhanced in a hyperlipidemic mouse model. Oncogene 32 961-967. (doi:10.1038/onc.2012.113)

Published by Bioscientifica Ltd 
Anderson GL, Limacher M, Assaf AR, Bassford T, Beresford SA, Black H, Bonds D, Brunner R, Brzyski R, Caan B et al. 2004 Effects of conjugated equine estrogen in postmenopausal women with hysterectomy: the Women's Health Initiative randomized controlled trial. Journal of the American Medical Association 291 1701-1712. (doi:10.1001/jama.291. 14.1701)

Barros RP \& Gustafsson JA 2011 Estrogen receptors and the metabolic network. Cell Metabolism 14 289-299. (doi:10.1016/j.cmet. 2011.08.005)

Barros RP, Machado UF, Warner M \& Gustafsson JA 2006 Muscle GLUT4 regulation by estrogen receptors ER $\beta$ and ER $\alpha$. PNAS 103 1605-1608. (doi:10.1073/pnas.0510391103)

Bhupathiraju SN \& Manson JE 2014 Menopausal hormone therapy and chronic disease risk in the Women's Health Initiative: is timing everything? Endocrine Practice 20 1201-1213. (doi:10.4158/ EP14205.RA)

Bryzgalova G, Gao H, Ahren B, Zierath JR, Galuska D, Steiler TL, DahlmanWright K, Nilsson S, Gustafsson JA, Efendic S et al. 2006 Evidence that oestrogen receptor- $\alpha$ plays an important role in the regulation of glucose homeostasis in mice: insulin sensitivity in the liver. Diabetologia 49 588-597. (doi:10.1007/s00125-005-0105-3)

Camporez JP, Jornayvaz FR, Lee HY, Kanda S, Guigni BA, Kahn M, Samuel VT, Carvalho CR, Petersen KF, Jurczak MJ et al. 2013 Cellular mechanism by which estradiol protects female ovariectomized mice from high-fat diet-induced hepatic and muscle insulin resistance. Endocrinology 154 1021-1028. (doi:10.1210/en.2012-1989)

Carr MC 2003 The emergence of the metabolic syndrome with menopause. Journal of Clinical Endocrinology and Metabolism 88 2404-2411. (doi:10.1210/jc.2003-030242)

Chlebowski RT \& Anderson GL 2012 Changing concepts: menopausal hormone therapy and breast cancer. Journal of National Cancer Institute 104 517-527. (doi:10.1093/jnci/djs014)

Choi SB, Jang JS \& Park S 2005 Estrogen and exercise may enhance $\beta$-cell function and mass via insulin receptor substrate 2 induction in ovariectomized diabetic rats. Endocrinology 146 4786-4794. (doi:10.1210/en.2004-1653)

Cinti S, Mitchell G, Barbatelli G, Murano I, Ceresi E, Faloia E, Wang S, Fortier M, Greenberg AS \& Obin MS 2005 Adipocyte death defines macrophage localization and function in adipose tissue of obese mice and humans. Journal of Lipid Research 46 2347-2355. (doi:10.1194/jlr. M500294-JLR200)

Clark JB, Palmer CJ \& Shaw WN 1983 The diabetic Zucker fatty rat. Proceedings of Society Experimental Biology and Medicine 173 68-75. (doi:10.3181/00379727-173-41611)

Coughlin SS, Calle EE, Teras LR, Petrelli J \& Thun MJ 2004 Diabetes mellitus as a predictor of cancer mortality in a large cohort of US adults. American Journal of Epidemiology 159 1160-1167. (doi:10.1093/aje/ kwh161)

De Marinis E, Martini C, Trentalance A \& Pallottini V 2008 Sex differences in hepatic regulation of cholesterol homeostasis. Journal of Endocrinology 198 635-643. (doi:10.1677/JOE-08-0242)

Donahue RP, Bean JA, Donahue RA, Goldberg RB \& Prineas RJ 1997 Insulin response in a triethnic population: effects of sex, ethnic origin, and body fat. Miami Community Health Study. Diabetes Care 20 1670-1676. (doi:10.2337/diacare.20.11.1670)

Espeland MA, Marcovina SM, Miller V, Wood PD, Wasilauskas C, Sherwin R, Schrott H \& Bush TL 1998 Effect of postmenopausal hormone therapy on lipoprotein(a) concentration. PEPI Investigators. Postmenopausal estrogen/progestin interventions. Circulation 97 979-986. (doi:10.1161/01.CIR.97.10.979)

Fernandez AM, Kim JK, Yakar S, Dupont J, Hernandez-Sanchez C, Castle AL, Filmore J, Shulman GI \& Le Roith D 2001 Functional inactivation of the IGF-I and insulin receptors in skeletal muscle causes type 2 diabetes. Genes and Development 15 1926-1934. (doi:10.1101/gad.908001)

Gonzalez C, Alonso A, Alvarez N, Diaz F, Martinez M, Fernandez S \& Patterson AM 2000 Role of $17 \beta$-estradiol and/or progesterone on insulin sensitivity in the rat: implications during pregnancy. Journal of Endocrinology 166 283-291. (doi:10.1677/joe.0.1660283)

Heine PA, Taylor JA, Iwamoto GA, Lubahn DB \& Cooke PS 2000 Increased adipose tissue in male and female estrogen receptor- $\alpha$ knockout mice. PNAS 97 12729-12734. (doi:10.1073/pnas.97.23.12729)

Hursting SD, Digiovanni J, Dannenberg AJ, Azrad M, Leroith D, DemarkWahnefried W, Kakarala M, Brodie A \& Berger NA 2012 Obesity, energy balance, and cancer: new opportunities for prevention. Cancer Prevention Research 5 1260-1272. (doi:10.1158/1940-6207. CAPR-12-0140)

Jones ME, Thorburn AW, Britt KL, Hewitt KN, Wreford NG, Proietto J, Oz OK, Leury BJ, Robertson KM, Yao S et al. 2000 Aromatase-deficient (ArKO) mice have a phenotype of increased adiposity. PNAS 97 12735-12740. (doi:10.1073/pnas.97.23.12735)

Kitahara CM, BerringtondeGonzalez A, Freedman ND, Huxley R, Mok Y, Jee SH \& Samet JM 2011 Total cholesterol and cancer risk in a large prospective study in Korea. Journal of Clinical Oncology 29 1592-1598. (doi:10.1200/JCO.2010.31.5200)

Klebig ML, Wilkinson JE, Geisler JG \& Woychik RP 1995 Ectopic expression of the agouti gene in transgenic mice causes obesity, features of type II diabetes, and yellow fur. PNAS 92 4728-4732. (doi:10.1073/pnas.92.11. 4728)

LaCroix AZ, Chlebowski RT, Manson JE, Aragaki AK, Johnson KC, Martin L, Margolis KL, Stefanick ML, Brzyski R, Curb JD et al. 2011 Health outcomes after stopping conjugated equine estrogens among postmenopausal women with prior hysterectomy: a randomized controlled trial. Journal of the American Medical Association 305 1305-1314. (doi:10.1001/jama.2011.382)

Larsson SC, Mantzoros CS \& Wolk A 2007 Diabetes mellitus and risk of breast cancer: a meta-analysis. International Journal of Cancer $\mathbf{1 2 1}$ 856-862. (doi:10.1002/ijc.22717)

Lemieux C, Phaneuf D, Labrie F, Giguere V, Richard D \& Deshaies Y 2005 Estrogen receptor $\alpha$-mediated adiposity-lowering and hypocholesterolemic actions of the selective estrogen receptor modulator acolbifene. International Journal of Obesity 29 1236-1244. (doi:10.1038/sj.ijo. 0803014)

Louet JF, LeMay C \& Mauvais-Jarvis F 2004 Antidiabetic actions of estrogen: insight from human and genetic mouse models. Current Atherosclerosis Reports 6 180-185. (doi:10.1007/s11883-004-0030-9)

Lovejoy JC, Champagne CM, de Jonge L, Xie H \& Smith SR 2008 Increased visceral fat and decreased energy expenditure during the menopausal transition. International Journal of Obesity 32 949-958. (doi:10.1038/ijo. 2008.25)

Makin G \& Dive C 2001 Modulating sensitivity to drug-induced apoptosis: the future for chemotherapy? Breast Cancer Research 3 150-153. (doi:10.1186/bcr289)

Margolis KL, Bonds DE, Rodabough RJ, Tinker L, Phillips LS, Allen C, Bassford T, Burke G, Torrens J \& Howard BV 2004 Effect of oestrogen plus progestin on the incidence of diabetes in postmenopausal women: results from the Women's Health Initiative Hormone Trial. Diabetologia 47 1175-1187. (doi:10.1007/s00125-004-1448-x)

Michels KB, Solomon CG, Hu FB, Rosner BA, Hankinson SE, Colditz GA, Manson JE \& Nurses' Health Study 2003 Type 2 diabetes and subsequent incidence of breast cancer in the Nurses' Health Study. Diabetes Care 26 1752-1758. (doi:10.2337/diacare.26.6.1752)

Morris PG, Hudis CA, Giri D, Morrow M, Falcone DJ, Zhou XK, Du B, Brogi E, Crawford CB, Kopelovich $\mathrm{L}$ et al. 2011 Inflammation and increased aromatase expression occur in the breast tissue of obese women with breast cancer. Cancer Prevention Research 4 1021-1029. (doi:10.1158/ 1940-6207.CAPR-11-0110)

Novosyadlyy R \& LeRoith D 2010 Hyperinsulinemia and type 2 diabetes: impact on cancer. Cell Cycle 9 1449-1450. (doi:10.4161/cc.9.8.11512)

Novosyadlyy R, Lann DE, Vijayakumar A, Rowzee A, Lazzarino DA, Fierz Y, Carboni JM, Gottardis MM, Pennisi PA, Molinolo AA et al. 2010 Insulin-mediated acceleration of breast cancer development and 
progression in a nonobese model of type 2 diabetes. Cancer Research 70 741-751. (doi:10.1158/0008-5472.CAN-09-2141)

Nuutila P, Knuuti MJ, Maki M, Laine H, Ruotsalainen U, Teras M, Haaparanta M, Solin O \& Yki-Jarvinen H 1995 Gender and insulin sensitivity in the heart and in skeletal muscles. Studies using positron emission tomography. Diabetes 44 31-36. (doi:10.2337/diab.44.1.31)

Paik SG, Michelis MA, Kim YT \& Shin S 1982 Induction of insulindependent diabetes by streptozotocin. Inhibition by estrogens and potentiation by androgens. Diabetes 31 724-729. (doi:10.2337/diab.31. 8.724)

Paplomata E \& O'Regan R 2014 The PI3K/AKT/mTOR pathway in breast cancer: targets, trials and biomarkers. Therapeutic Advances in Medical Oncology 6 154-166. (doi:10.1177/1758834014530023)

Pei XF, Noble MS, Davoli MA, Rosfjord E, Tilli MT, Furth PA, Russell R, Johnson MD \& Dickson RB 2004 Explant-cell culture of primary mammary tumors from MMTV-c-Myc transgenic mice. In Vitro Cellular \& Developmental Biology. Animal 40 14-21. (doi:10.1290/1543706X $(2004) 40<14:$ ECOPMT $>2.0 . C O ; 2)$

Petrelli JM, Calle EE, Rodriguez C \& Thun MJ 2002 Body mass index, height, and postmenopausal breast cancer mortality in a prospective cohort of US women. Cancer Causes \& Control 13 325-332. (doi:10. 1023/A:1015288615472)

Picard F, Wanatabe M, Schoonjans K, Lydon J, O'Malley BW \& Auwerx J 2002 Progesterone receptor knockout mice have an improved glucose homeostasis secondary to $\beta$-cell proliferation. PNAS 99 15644-15648. (doi:10.1073/pnas.202612199)

Pierobon M \& Frankenfeld CL 2013 Obesity as a risk factor for triplenegative breast cancers: a systematic review and meta-analysis. Breast Cancer Research and Treatment 137 307-314. (doi:10.1007/s10549-0122339-3)

Preston-Martin S, Pike MC, Ross RK, Jones PA \& Henderson BE 1990 Increased cell division as a cause of human cancer. Cancer Research $\mathbf{5 0}$ 7415-7421.

Puah JA \& Bailey CJ 1985 Insulinotropic effect of ovarian steroid hormones in streptozotocin diabetic female mice. Hormone Metabolic Research 17 216-218. (doi:10.1055/s-2007-1013496)

Robinson WR, Tse CK, Olshan AF \& Troester MA 2014 Body size across the life course and risk of premenopausal and postmenopausal breast cancer in Black women, the Carolina Breast Cancer Study, 1993-2001. Cancer Causes \& Control 25 1101-1117. (doi:10.1007/ s10552-014-0411-5)

Rogers NH, Perfield JW II, Strissel KJ, Obin MS \& Greenberg AS 2009 Reduced energy expenditure and increased inflammation are early events in the development of ovariectomy-induced obesity. Endocrinology 150 2161-2168. (doi:10.1210/en.2008-1405)

Russo J, Fernandez SV, Russo PA, Fernbaugh R, Sheriff FS, Lareef HM, Garber J \& Russo IH 2006 17- $\beta$-estradiol induces transformation and tumorigenesis in human breast epithelial cells. FASEB Journal 20 1622-1634. (doi:10.1096/fj.05-5399com)

Salpeter SR, Walsh JM, Ormiston TM, Greyber E, Buckley NS \& Salpeter EE 2006 Meta-analysis: effect of hormone-replacement therapy on components of the metabolic syndrome in postmenopausal women. Diabetes, Obesity \& Metabolism 8 538-554. (doi:10.1111/j.1463-1326. 2005.00545.x)

Sciacca L, Vigneri R, Tumminia A, Frasca F, Squatrito S, Frittitta L \& Vigneri P 2013 Clinical and molecular mechanisms favoring cancer initiation and progression in diabetic patients. Nutrition, Metabolism, and Cardiovascular Diseases 23 808-815. (doi:10.1016/j. numecd.2013.05.006)

Subbaramaiah K, Howe LR, Bhardwaj P, Du B, Gravaghi C, Yantiss RK, Zhou XK, Blaho VA, Hla T, Yang P et al. 2011 Obesity is associated with inflammation and elevated aromatase expression in the mouse mammary gland. Cancer Prevention Research 4 329-346. (doi:10.1158/ 1940-6207.CAPR-10-0381)

Sundaram S, Johnson AR \& Makowski L 2013 Obesity, metabolism and the microenvironment: Links to cancer. Journal of Carcinogenesis 1219. (doi:10.4103/1477-3163.119606)

Xu Y, Nedungadi TP, Zhu L, Sobhani N, Irani BG, Davis KE, Zhang X, Zou F, Gent LM, Hahner LD et al. 2011 Distinct hypothalamic neurons mediate estrogenic effects on energy homeostasis and reproduction. Cell Metabolism 14 453-465. (doi:10.1016/j.cmet.2011.08.009)

$\mathrm{Xu}$ CX, Zhu HH \& Zhu YM 2014 Diabetes and cancer: associations, mechanisms, and implications for medical practice. World Journal of Diabetes 5 372-380. (doi:10.4239/wjd.v5.i3.372)

Yakar S, Nunez NP, Pennisi P, Brodt P, Sun H, Fallavollita L, Zhao H, Scavo L, Novosyadlyy R, Kurshan $\mathrm{N}$ et al. 2006 Increased tumor growth in mice with diet-induced obesity: impact of ovarian hormones. Endocrinology 147 5826-5834. (doi:10.1210/en.2006-0311)

Yepuru M, Eswaraka J, Kearbey JD, Barrett CM, Raghow S, Veverka KA, Miller DD, Dalton JT \& Narayanan R 2010 Estrogen receptor- $\{\beta\}$ selective ligands alleviate high-fat diet- and ovariectomy-induced obesity in mice. Journal of Biological Chemistry 285 31292-31303. (doi:10.1074/jbc.M110.147850)

Yue W, Yager JD, Wang JP, Jupe ER \& Santen RJ 2013 Estrogen receptordependent and independent mechanisms of breast cancer carcinogenesis. Steroids 78 161-170. (doi:10.1016/j.steroids.2012.11.001)

Received in final form 7 September 2015

Accepted 10 September 2015

Accepted Preprint published online 17 September 2015
(C) 2015 Society for Endocrinology Printed in Great Britain 